https://doi.org/10.15407/mics2021.12.024

УДК 94(477.54)»20»

\title{
Роман Любавський,
}

кандидат історичних наук, Харківський національний університет імені В. Н. Каразіна Lubavsky@karazin.ua

https://orcid.org/0000-0003-3496-9699

\section{МУРАЛИ ХАРКОВА: \\ ПРОСТІР , ПАМ'ЯТЬ, ПОЛІТИКА 1}

"“Топонімічна химера": верейменування в Харкові, конфлікт пам'ятей та ідентичностей», реалізованого за підтримки Харківського офісу Фонду Конрада Аденауера.

У статті проаналізовано мурали Харкова, що з'явилися у місті упродовж 2008-2020 рр. 24 арт-об'єкти розглянуто як медіатори історичної пам'яті, що ретранслюють різні наративи/ дискурси: радянсько-ностальгійний, регіональний, національний; виявлено контекст їх створення, практики їх інструменталізації різними агентами історичної пам'яті.

Ініціатором появи муралів, що репрезентують радянсько-ностальгійний дискурс, $є$ міська влада. Найбільше таких зображень з'явилося у місті у 2013 р., напередодні святкування Дня міста та відзначення 70-річчя визволення від німецької окупації. Очільники міста ініціювали проєкт «Гордость Харькова», у межах реалізації якого у місті було створено мурали із зображенням харків'ян, життя та творчість яких безпосередньо пов'язані із подіями «Великої Вітчизняної війни» (В. Гризодубова, Г. Жуков, К. Шульженко, П. Набойченко). Ці та інші зображення ілюструють радянсько-ностальгійний і регіональний виміри публічного простору міста. Вони найчастіше поєднуються між собою, латентно або прямо актуалізуючи фантомні болі «першої столиці». Такі зображення завжди персоніфіковані. Критерії вибору персоналії - уродженець та мешканець Харкова, відомий на загальносоюзному рівні (Л. Гурченко, І. Бугримова та ін.). Від 2014 р. спостерігаємо появу в місті зображень загальнонаціональних символів, що можна інтерпретувати як спробу вписати Харків до національного наративу, продемонструвати перебування міста у соге українського політичного проєкту. Такі мурали є персоніфікованими й абстрактно-символічними (Т. Шевченко, воїни - герої Крут, герб України, петриківський розпис, вишиванка (орнамент), лялька-мотанка та ін.). Ініціаторами створення цих муралів $€$ 
2 Ковалевська, 0. (2018). Візуальні студї̈. В В. Смолій (Ред.), Нариси з соціокультурної історії українського історієписання: субдисциплінарні напрями: колект. монографія (с. 120 , 142). Київ.

з Там само, 144.

4 Аванесов, С. Что можно назвать визу альной семиотикой? Праксема. Проблемы вихуальной семиотики, 1, 10-22.

5 Штомпка, П. (2007). Визуальная социология. Фотография как метод исследования. Москва.

6 Александров, E. (2003). Опыт рассмотрения теоретических и методологических проблем визуальной антропологии. Москва.

7 Ковалевська, 0. Візуальні студії, 141.

8 Замятин, Д. (2010). Гуманитарная география: предмет изучения и основные направления развития. Общественные

міська влада і громада міста. Зазначимо, що національний наратив майже ніколи не поєднувався з регіональним. Утім, зафіксовано випадки, коли радянсько-ностальгійний, регіональний та національний дискурси проектувалися в одному зображенні. Приміром, є мурал, на якому зображено загиблих воїнів-афганців і воїнів, що загинули під час АТО. Це може свідчити про багатошаровість історичної пам’яті мешканців регіону.

Отже, аналіз муралів як медіаторів певного образу минулого у просторі Харкова засвідчив, що з 25 муралів, створених у 2008-2020 рр., які мають яскраво виражене ідеологічне забарвлення, 13 ретранслюють у просторі міста Харкова радянсько-ностальгійний наратив, 12 - регіональний, 10 - національний.

Ключові слова: мурали, Харків, публічний простір, історична політика.

За висновками науковців, сьогодні відбулось кардинальне розширення сфери візуального у громадському житті, візуалізація оточує людину на всіх рівнях іiі буття ${ }^{2}$ Простір сучасних міст перенасичений різними креолізованими текстами, до яких традиційно відносять рекламні повідомлення, продукти графічного дизайну, плакати, банери тощо. Споживання візуальних об’єктів $\epsilon$ звичною культурною практикою містян. Подорож містом передбачає візуальну комунікацію людини із довколишнім світом. На думку О. Ковалевської, візуальне повідомлення має значний потенціал і здатність інформувати та освічувати, впливати на соціум та його окремих представників ${ }^{3}$. Цей процес сьогодні вивчають у межах таких дослідницьких підходів, як візуальна семіотика $^{4}$, соціологія ${ }^{5}$, антропологія ${ }^{6}$, гуманітарна географія тощо. Об’єктами візуальної куль- тури серед інших є мурали ${ }^{7}$. Метою цієї розвідки $є$ виявлення та аналіз муралів Харкова як маркерів історичної політики та медіаторів пам'яті у міському просторі. Для цього дослідження важливими були методологічні підходи імажинальної географії, центральною категорією якої є поняття географічного образу - образ території, місця, культурного ландшафту. Його аналіз відбувається 3 урахуванням когнітивно-географічного контексту і локального (регіонального, просторового) міфу ${ }^{8}$. Тому завданням роботи було проаналізувати мурали Харкова 3 погляду їх належності/ретрансляції радянського, регіонального та національного дискурсу. Їхні сюжети та контексти створення символічно вписують Харків до загальносоюзного чи загальнонаціонального українського політичного і культурного простору, або підсилюють його регіональне значення. До про- 
9 Касьянов, Г. (Ред.). (2018). Політика i пам'ять. Дніпро - Запоріжн одеса - Харків. Від 1990-x до сьогодні. Львів; Посохов, С. (2017). Професійні історики і політика пам'яті в харківському регіоні (доба незалежної України). В Історіограбічні та джерелознавчі проблеми історї̈ україни (с. 277-291). Дніпропетровськ; Боженко, А. (2020). Столичний Харків: утопія, конструктивізм, пам'ять (19191934 pp.). City History, Culture, Society, 8, 36-44.

10 Мусієздов, 0. (2011). Ідентифікація Харкова: досвід конструювання образу міста. Схід-Захід: Історико-культурологічний збірник, 15, 217-234.

11 Культурний проєкт «П'ятий Харків» розпочинає новий сезон. Retrieved from https://kharkivoda.gov.ua/news/104979.

12 Топ-12 муралов Харькова. Retrieved from https://kharkivoda.gov.ua/

news/104979; https: //mykharkov.info/ news/top-12-muralov-harkova-10027. html.

13 Самые красивые и креативные муралы, арт-объекты и граффити Харькова. Retrieved from https://mural.kh.ua/.

14 Ковалевська, 0. Візуальні студії, 152 блем ідентичності харків'ян та образу міста, політики пам'яті в регіоні вже неодноразово зверталися історики ${ }^{9}$, соціологи ${ }^{10}$, митці й письменники ${ }^{11}$.

Останніми роками вулиці і площі, монументи і пам'ятники стали ареною боротьби різних візій минулого та відповідно майбутнього України. Трансформація міського простору із початком декомунізації отримала нові імпульси. Суспільно-політична ситуація у країні зумовила збільшення суспільного запиту на зміну урбаністичного ландшафту. Журналісти регіональних та центральних видань і телеканалів регулярно складають рейтинги найкращих муралів міста ${ }^{12}$. Упродовж останніх років можемо спостерігати збільшення кількості арт-об'єктів (мурали, графіті, стріт-арт тощо) вуличного мистецтва у місті. Вони мають різне смислове навантаження, від нейтрального і філософського до ідеологічного. Виявити їхню кількість досить складно, адже простір міста повсякчас змінюється, одні зображення зникають, інші з'являються, їх офіційного реєстру немає. Втім, є волонтерські проєкти, що фіксують мурали у міському ландшафті. Зокрема, аналіз бази даних проєкту «МуХа Муралы Харькова», створеного із залученням ГІС-технологій, виявив 57 (найбільших) муралів міста ${ }^{13}$. За допомогою методів залученого спостереження та візуального аналі- зу міського простору було виявлено мурали, що мають чітке символічне навантаження та репрезентують культурні орієнтири місцевої влади, оскільки вони створюються за рахунок місцевого бюджету, та запити громадськості. Можемо констатувати, що яскраво виражене символічне (до певної міри ідеологічне) значення мають 24 об' єкти (див. табл.). До аналізу також було долучено один об'єкт із Харківської області (Лозова) як показовий приклад.

Мурали проаналізовано як візуальні icторичні джерела за усталеним алгоритмом: опис (кого/що зображено, аналіз композиції тощо), первинна інтерпретація (визначення того, ким є зображені постаті, які об'єкти чи символічні предмети зображено, яке інформаційне навантаження вони мають), вторинна інтерпретація (визначення контексту появи джерела муралу) ${ }^{14}$. Звісно, аналіз цих муралів не дає вичерпного уявлення про домінантний та релевантний образ пам'яті про минуле у регіоні. Втім, така розвідка, на нашу думку, демонструє широту і перспективу дисциплінарного поля історичної урбаністики.

Одні з перших муралів у місті з'явилися у 2008 р. під час реалізації проекту Муніципальної галереї «Пушкін на Пушкінській і Гоголь на Гоголя». Їх створили провідні українські художники, харків'яни Р. Мінін 
Мурали Харкова

\begin{tabular}{|c|c|c|c|c|c|c|}
\hline № & $\begin{array}{l}\text { Назва, хто/що } \\
\text { зображений/о }\end{array}$ & Рік & Наратив & Агентність & Чому присвячено & Гендер \\
\hline 1 & $\begin{array}{l}\text { «Гоголь на } \\
\text { Гоголя» }\end{array}$ & 2008 & Національний & Громада & & Чол. \\
\hline 2 & $\begin{array}{l}\text { Т. Шевченко, } \\
\text { О. Пушкін }\end{array}$ & 2010 & $\begin{array}{l}\text { Національний, } \\
\text { радянсько- } \\
\text { ностальгійний }\end{array}$ & Міська влада & & Чол. \\
\hline 3 & В. Гризодубова & 2013 & $\begin{array}{l}\text { Радянсько- } \\
\text { ностальгійний, } \\
\text { регіональний }\end{array}$ & Міська влада & $\begin{array}{l}\text { 70-річчю визволення } \\
\text { Харкова від німецької } \\
\text { окупації та до Дня міста }\end{array}$ & Жін. \\
\hline 4 & $\begin{array}{l}\text { Маршал Жуков } \\
\text { на коні }\end{array}$ & 2013 & $\begin{array}{l}\text { Радянсько- } \\
\text { ностальгійний }\end{array}$ & Міська влада & $\begin{array}{l}\text { 70-річчю визволення } \\
\text { Харкова від німецької } \\
\text { окупації та до Дня міста }\end{array}$ & Чол. \\
\hline 5 & К. Шульженко & 2013 & $\begin{array}{l}\text { Радянсько- } \\
\text { ностальгійний, } \\
\text { регіональний }\end{array}$ & Міська влада & $\begin{array}{l}\text { 70-річчю визволення } \\
\text { Харкова від німецької } \\
\text { окупації та до Дня міста }\end{array}$ & Жін. \\
\hline 6 & П. Набойченко & 2013 & $\begin{array}{l}\text { Радянсько- } \\
\text { ностальгійний, } \\
\text { регіональний }\end{array}$ & Міська влада & $\begin{array}{l}\text { 70-річчю визволення } \\
\text { Харкова від німецької } \\
\text { окупації та до Дня міста }\end{array}$ & Чол. \\
\hline 7 & Л. Биков & 2013 & $\begin{array}{l}\text { Радянсько- } \\
\text { ностальгійний, } \\
\text { регіональний }\end{array}$ & Міська влада & $\begin{array}{l}\text { 70-річчю визволення } \\
\text { Харкова від німецької } \\
\text { окупації та до Дня міста }\end{array}$ & Чол. \\
\hline 8 & Ю. Гагарін & 2013 & $\begin{array}{l}\text { Радянсько- } \\
\text { ностальгійний }\end{array}$ & Міська влада & & Чол. \\
\hline 9 & Л. Ландау & 2013 & $\begin{array}{l}\text { Радянсько- } \\
\text { ностальгійний }\end{array}$ & Міська влада & & Чол. \\
\hline 10 & Кукла-мотанка & 2013 & Національний & Громада & & Жін. \\
\hline
\end{tabular}




\begin{tabular}{|c|c|c|c|c|c|c|}
\hline 11 & Т. Шевченко & 2014 & Національний & Міська влада & $\begin{array}{l}\text { До 200-ї річниці від } \\
\text { дня народження }\end{array}$ & Чол. \\
\hline 12 & Герб України & 2015 & Національний & Громада & & \\
\hline 13 & Н. Фатєєва & 2016 & $\begin{array}{l}\text { Радянсько- } \\
\text { ностальгійний, } \\
\text { регіональний }\end{array}$ & Міська влада & До Дня міста & Жін. \\
\hline 14 & Л. Гурченко & 2016 & $\begin{array}{l}\text { Радянсько- } \\
\text { ностальгійний, } \\
\text { регіональний }\end{array}$ & Міська влада & До Дня міста & Жін. \\
\hline 15 & Герб Харкова & 2016 & Регіональний & Громада & & \\
\hline 16 & Герої Крут & 2016 & Національний & Громада & До 98-ї річниці події & \\
\hline 17 & $\begin{array}{l}\text { Успенський } \\
\text { собор }\end{array}$ & 2017 & Регіональний & $\begin{array}{l}\text { Громада, } \\
\text { міська влада }\end{array}$ & До Дня міста & \\
\hline 18 & $\begin{array}{l}\text { Петриківський } \\
\text { розпис }\end{array}$ & 2017 & Національний & Міська влада & & \\
\hline 19 & I. Бугримова & 2018 & $\begin{array}{l}\text { Радянсько- } \\
\text { ностальгійний, } \\
\text { регіональний }\end{array}$ & Міська влада & & Жін. \\
\hline 20 & К. Скрябін & 2018 & Національний & $\begin{array}{l}\text { Громада, } \\
\text { міська влада }\end{array}$ & & Чол. \\
\hline 21 & I. Дунаєвський & 2019 & $\begin{array}{l}\text { Радянсько- } \\
\text { ностальгійний, } \\
\text { регіональний }\end{array}$ & Міська влада & & Чол. \\
\hline 22 & $\begin{array}{l}\text { Вишиванка } \\
\text { (орнамент) }\end{array}$ & 2019 & Національний & Міська влада & & \\
\hline 23 & $\begin{array}{l}\text { Символи } \\
\text { Харкова }\end{array}$ & 2020 & Регіональний & Міська влада & & \\
\hline 24 & $\begin{array}{l}\text { «Контррозвідка } \\
\text { поруч» }\end{array}$ & 2020 & Національний & Громада & & \\
\hline
\end{tabular}



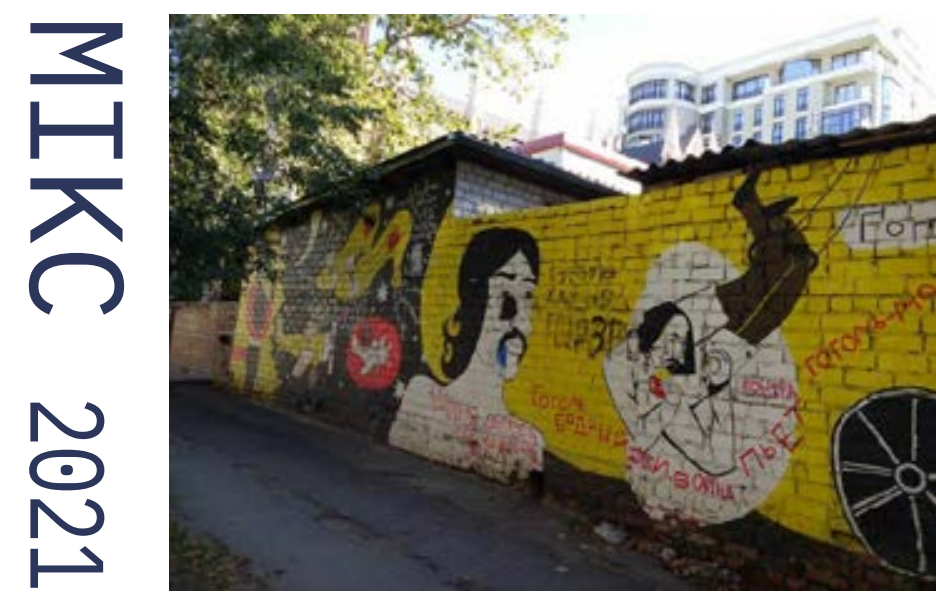

Рuc. 1. Мурал «Гоголь на Гоголя»

15 В воскресенье в Харькове пройдет фестиваль «День одной улицы». Retrieved from https://www.city. kharkov.ua/ru/news/u-nedilyu-vkharkovi-proyde-festival-den-odnieivulitsi-30615. html.

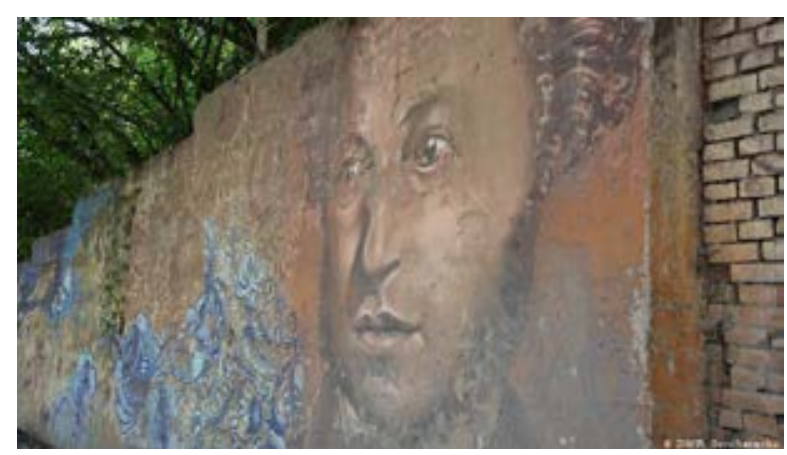

Puc. 3. Мурал «Олександр Пушкін» та Г. Зеньківський. Мурали із зображенням М. Гоголя намальовані на будинках обабіч вулиці (рис. 1). Зміна політичної ситуації в країні у 2014 р. підсилила національну складову образу письменника. У 2016 р. під час святкування Дня однієї вулиці - мистецької акції, організованої ініціативною групою «День музики», відбулися традиційний ярмарок, цикл лекцій та екскурсій містом. Організатори акції не порушували популярні у публіцистиці та медіа проблеми національної ідентифікації М. Гоголя. Однак сама ідея фестивалю та обрання конкретної вулиці не були випадковими. Загалом деполітизований, мистецький захід поєднує історію міста iз національним дискурсом. Національним, оскільки М. Гоголь входить до пантеону символів української культури. Разом із тим, захід мав чіткий регіональний вимір, який підкреслював особливість та мультикультурність міста. Зокрема, екскурсовод О. Стадник у своєму інтерв'ю наголосив на тому, що «история этой улицы очень показательна в масштабах исторического и культурного облика Харькова... Таким образом, улица Гоголя, по меньшей мере в дореволюционное время, была одной из самых космополитичных в нашем космополитичном городе». Вочевидь, таке визначення міста сподобалось його очільникам, оскільки саме цей фрагмент інтерв'ю було опубліковано на сайті міської ради ${ }^{15}$.
У 2010 р. у місті з'явився перший мурал із зображенням Т. Шевченка (рис. 2). Поява таких і подібних символів у міському просторі, як правило, зумовлена вшануванням «Шевченківських місць». Проте Т. Шевченко у Харкові ніколи не був. Тому поява муралу з його зображенням є символічною дією. Особливим є те, що зображення Кобзаря з'явилося у міському просторі одночасно

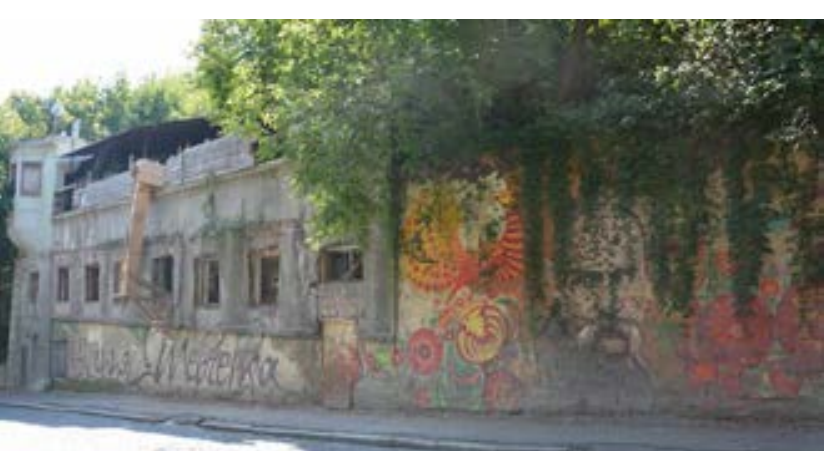

Рис. 2. Мурал «Тарас Шевченко»

iз зображенням О. Пушкіна (рис. 3), власне, один навпроти одного. Ці зображення розташовані на Бєлгородському узвозі, де сходяться вулиці Пушкінська та Шевченка - вуличні магістралі, названі на честь національних героїв і символів двох окремих народів, що перебували під дахом однієї імперії. Розміщення поруч цих представників свого часу можна вважати репрезентацією радянсько- 
16 Кравченко, В. (2010). Харьков/ Харків: столича Пограничья. Вильнюс: Европейский гуманитарный университет, 283.

17 Див. про це: Черномаз, П. (2012). Еврорегион «Слобожанщина»: становление и роль в развитии украинско-российского трансграничного сотрудничества, Междисииллинарные исследования в науке и образовании: Экономические науки, 1. Retrieved from http://ekhnuir.univer. kharkov.ua/handle/123456789/6669.

18 Портрет Гризодубовой величиной с дом - на Московском проспекте. Retrieved from https://www.mediaport. ua/portret-grizodubovoy-velichinoy- го дискурсу «братніх народів», концепту пограниччя регіону. До речі, за висновками В. Кравченка, українсько-російський кордон у межах Харківщини після розпаду СРСР не мав конфліктогенного потенціалу ${ }^{16}$. Зауважимо, що на початку 2000-х рр. політичні еліти Харкова та Бєлгорода активно шукали шляхи співпраці, зокрема було створено міжрегіональний проєкт «Єврорегіон «Слобожанщина» ${ }^{17}$. До цього проєкту була залучена й академічна спільнота. Упродовж 2009-2013 рр. проводили студентські наукові школи на тему «Історико-культурна спадщина Єврорегіону “Слобожанщина”». Отже, поява муралів із зображенням Т. Шевченка та О. Пушкіна є логічною у контексті міжрегіональних ініціатив 2003-2013 рр.

Сім муралів міста, що мають ідеологічне семантичне навантаження, 3'явилися у 2013 р. Їх поява зумовлена активністю міської ради, яка в той час була провідним агентом пам’яті. У 2013 р. Харків відзначав 70-річчя визволення від німецької окупації. Очільники міста ініціювали проєкт «Гордость Харькова», в межах реалізації якого у місті з'явились мурали із зображенням харків'ян, життя та творчість яких безпосередньо пов'язані з подіями «Великої Вітчизняної війни». У центpi міста розташовані портрети льотчиці, першої жінки-героя СРСР В. Гризодубової 18 (рис. 4) та співачки К. Шульженко (рис. 5).

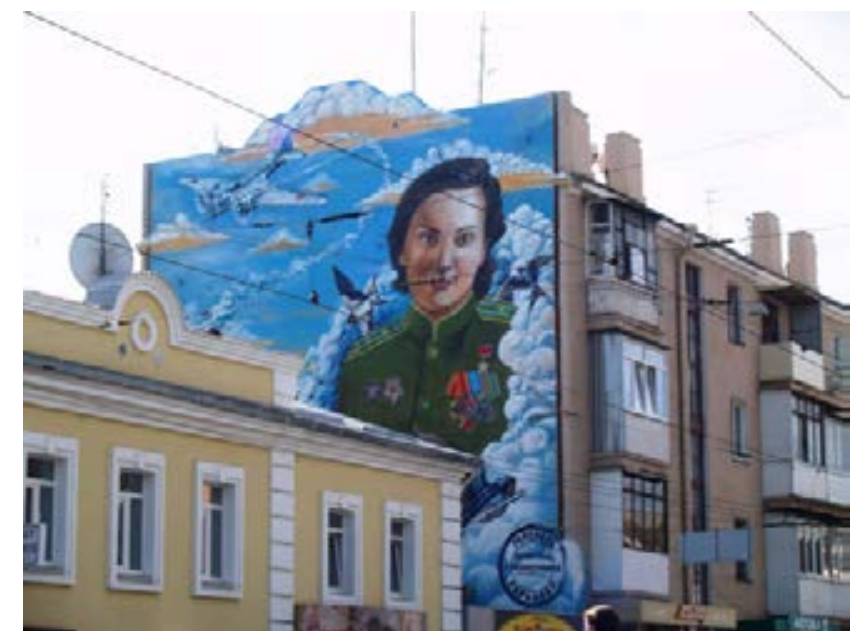

Рис. 4. Мурал «Валентина Гризодубова»

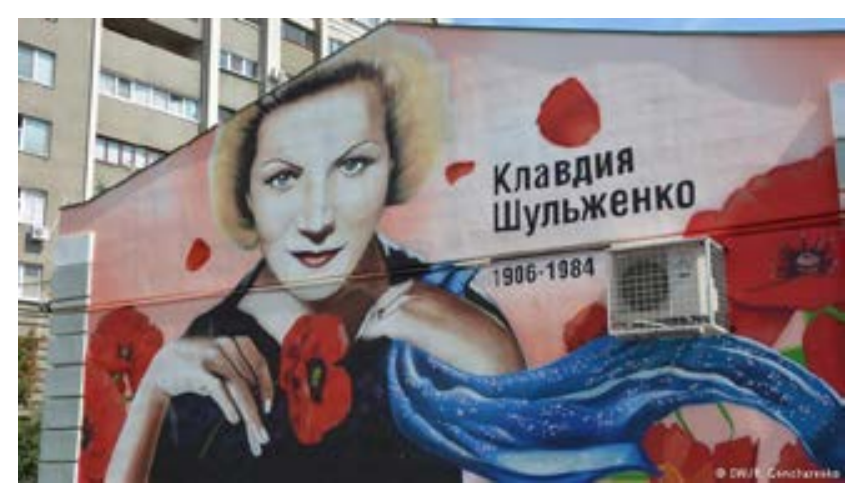

Рuc. 5. Мурал «Клавдія Шульженко» 


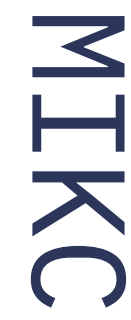

$\underset{13}{3}$

19 Одну из стен харьковского дома украсил маршал Жуков на вальсирующем коне. Retrieved from https:// www. 057.ua/news/706954/odnu-iz-stenharkovskogo-doma-ukrasil-marsalzukov-na-valsiruusem-kone-fotofakt .

20 В Харькове туристов «удивил» мурал с «георгиевской ленточкой». Retrieved from https://kh.depo.ua/ rus/kh/u-harkovi-turistiv-zdivuvavmural-iz-georgiyivskoyu-strichkoyufoto-20171129684617.

21 Мурал Леониду Быкову. Retrieved from https://mural.kh.ua/bykov/.
Ці зображення $\epsilon$ найбільш нейтральними, хоча й відповідають головним канонам радянсько-ностальгійного дискурсу. Ідеологічно марковане й відверто невдале 3 художнього погляду зображення Г. Жукова (рис. 6) на коні на тлі святкового салюту 19 розміщено на околиці міста. Прикметно, що «негативної преси» це зображення не зібрало. Вочевидь, причиною інформаційного штилю було віддалене від центру міста розташування. Ще один мурал у межах проєкту «Гордость Харькова» присвячено П. Найбойченку (рис. 7), герою СРСР.

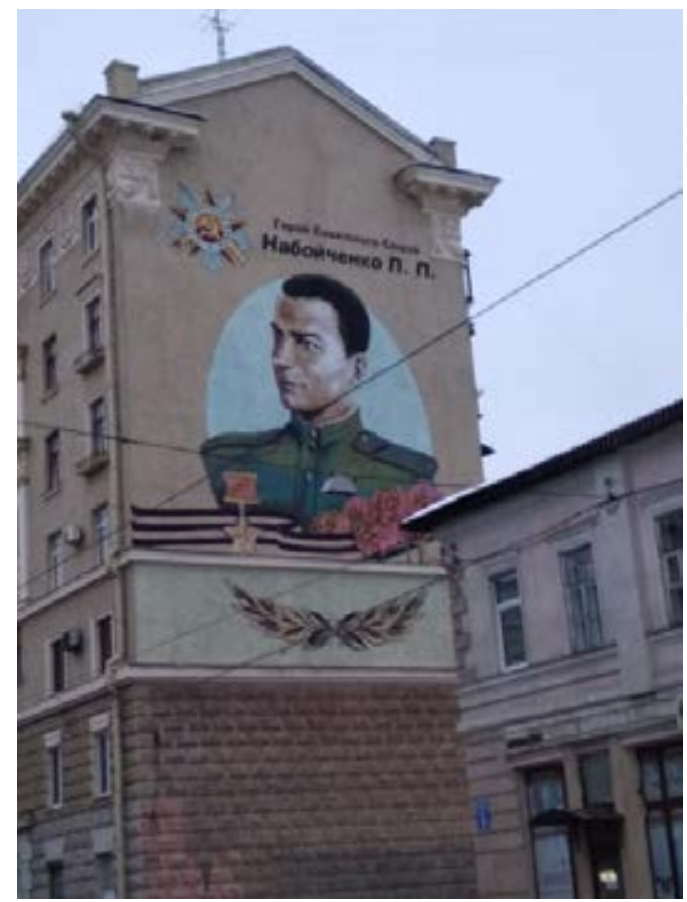

Воїна зображено із георгіївською стрічкою ${ }^{20}$. Одним із символів Харкова $є$ режисер та актор Л. Биков (рис. 8), який став відомим після фільму «В бой идут одни

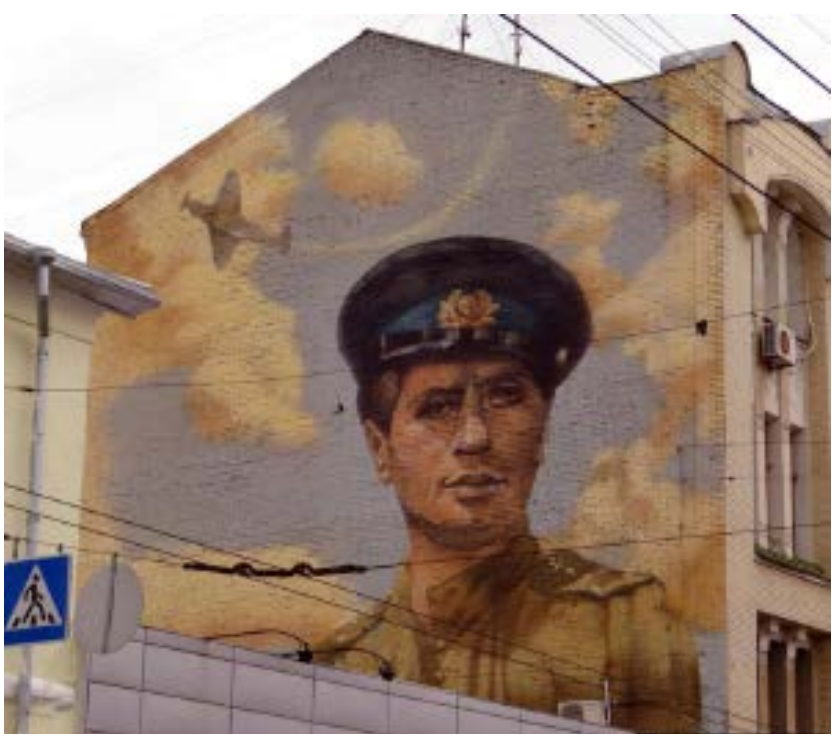

Рuc. 8. Мурал «Леонід Биков»

старики». Мурал із його зображенням розташовано у самому центрі міста ${ }^{21}$. Отже, зазначені образи репрезентують поєднання радянсько-ностальгійного та регіонального дискурсів. Радянськість виявляється у виборі героїв та контексті появи - 70-річчя від дня визволення міста. Поява цих муралів свідчить про те, що міські еліти у 2013 р. повністю перебували під впливом радянсько-ностальгійного дискурсу, із домішками регіоналізму. 


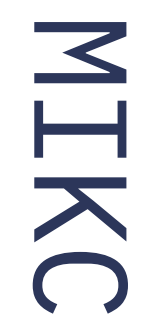

Рuc. 9. Мурал «Юрій Гагарін»

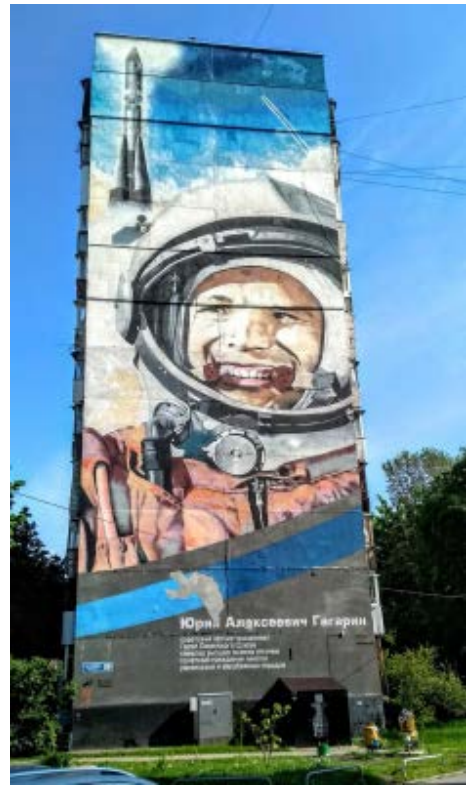



22 Мурал Юрий Гагарин. Retrieved from https://mural.kh.ua/gagarin/ .

23 Фотофакт: теперь за ХТЗ следит Лев Ландау. Retrieved from https:// $\mathrm{kh}$.vgorode.ua/news/dosuh_y_eda/184658fotofakt-teper-za-khtz-sledyt-lev-

landau.

24 Украинская кукла-мотанка. Retrieved from https://mural.kh.ua/kuklamotanka/.
Цього ж році у місті з'явились мурали, що ілюструють здобутки радянської науки, присвячені Ю. Гагаріну (рис. 9) ${ }^{22}$ та Л. Ландау (рис. 10) ${ }^{23}$.

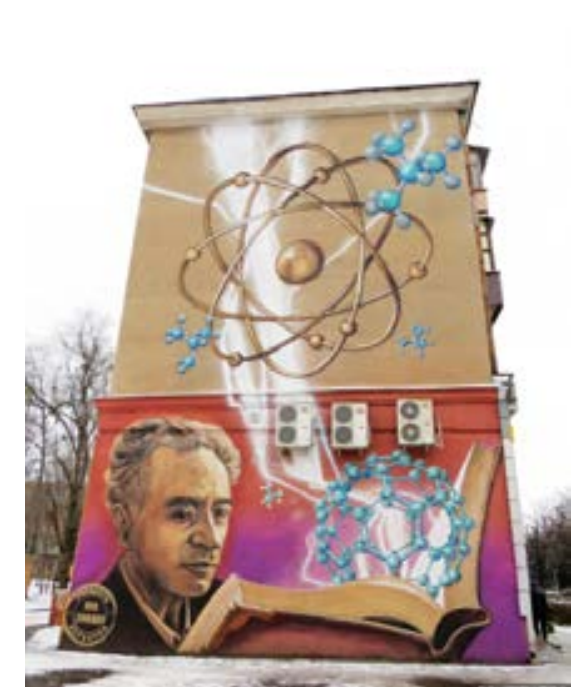

Рис. 10. Мурал «Лев Ландау»

Лише один із семи муралів, що з'явилися у просторі Харкова у 2013 р., репрезентує українську національну ідентичність міста. Це зображення ляльки-мотанки (рис. 11), яке створив французький художник Ж. Маллан у межах заходу «Французька весна», організованого Посольством Франції в Україні та Французьким інститутом в Україні ${ }^{24}$. Цей приклад демонструє, що українська ідентичність вбрана у шати класичного етнографізму XIX ст. і певною мірою дисонує з гаслами про Харків як сучасне місто молоді тощо.

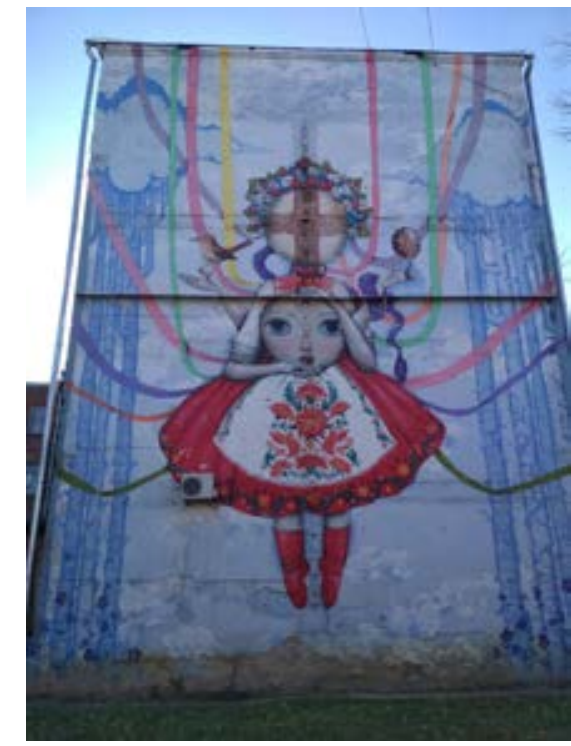

Puc. 11 Мурал

«Лялька-

мотанка»

Події, що сталися в Україні у 2014 р., загострили питання ідентичності й культури пам'яті. У Харкові з'явився другий мурал iз зображенням Т. Шевченка (рис. 12), що є

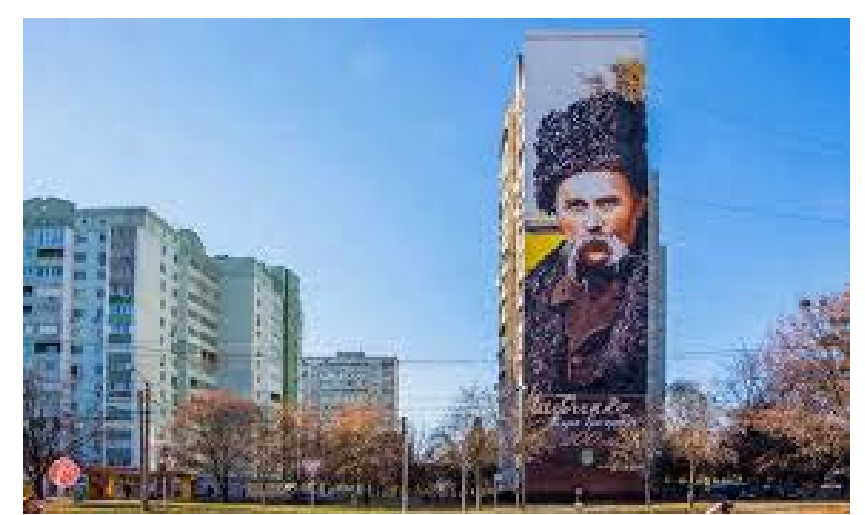

Рuc. 12. Мурал «Тарас Шевченко» 
25 Мурал Тарас Шевченко. Retrieved from https://mural.kh.ua/shevchenko/.

26 В Харькове появилось 15-метровое патриотичное граффити. Retrieved from https://www. newsroom.kh.ua/ news/v-harkove-poyavilos-15-metrovoepatriotichnoe-graffiti.

27 Багатоповерхівку в Харкові прикрасив барвистий мурал. Retrieved from https://www.segodnya.ua/ua/regions/ kharkov/mnogoetazhku-v-harkoveukrasil-krasochnyy-mural-744255.html .

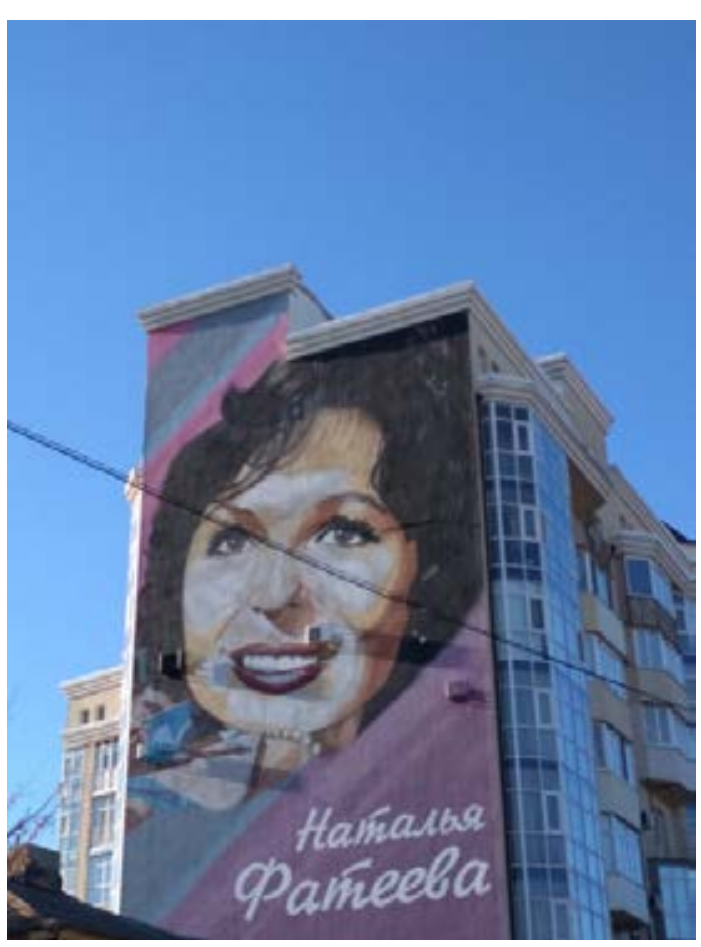

Рис. 14. Мурал «Наталя Фатєєва» найбільшим портретом Кобзаря ${ }^{25}$. Його було створено до 200-ї річниці 3 дня народження поета. В такий спосіб Харків продемонстрував належність до українського національного проєкту. Зазначимо, що громадські активісти, міська еліта, коли йдеться про образ «Український Харків», згадують лише хрестоматійного Т. Шевченка. Натомість не згадують представників української літератури і мистецтва, які проживали у будинку «Слово» в Харкові. Вони зробили значний внесок у розвиток української модерної культури напряму пов' язані з міським простором. Більшість цих митців були репресовані у 1930-х pp., тож «пригадування» про них може вступати у конфлікт із радянсько-ностальгійним дискурсом. Образ Т. Шевченка, який експлуатується у Харкові для маркування останнього як українського міста, за змістом - це радянізований образ Кобзаря у середовищі селянства. Все це ще раз підтверджує домінантність радянсько-ностальгійного дискурсу і загальну тенденцію до уникання політизації і конфронтації різних версій минулого у просторі Харкова.

У 2015 р. така тенденція зберіглася. Однак, з огляду на політичну ситуацію в країні і великий суспільний інтерес, на тлі недопущення проросійського сценарію та створення ХНР, простір міста збагатився ще одним національним символом - гербом України (рис. 13) ${ }^{26}$.

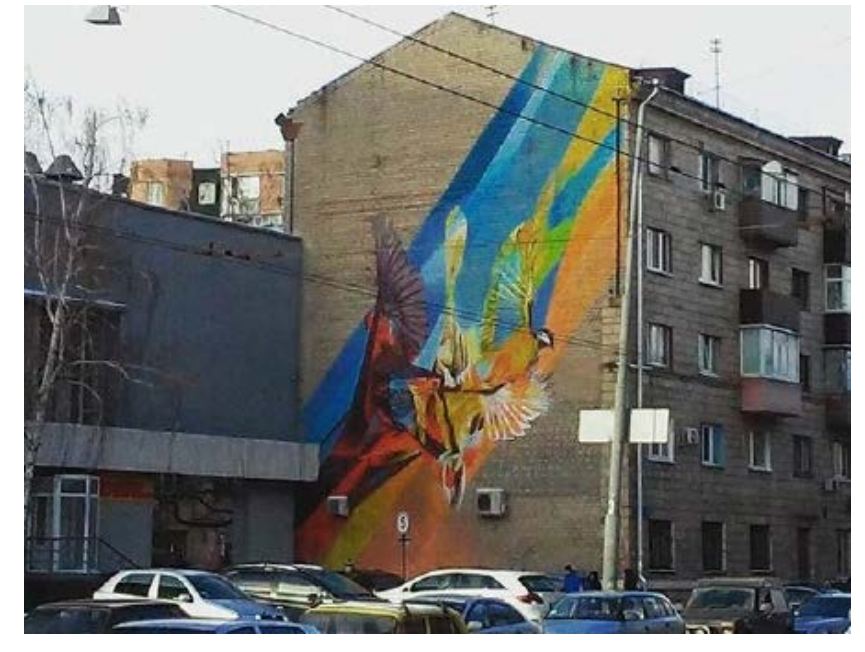

Рис. 13. Мурал «Герб України»

У 2016 р. відбулося стрімке збільшення кількості муралів у місті. Якщо упродовж 2014-2015 pр. у Харкові з'явилося два семантично навантажені мурали, то у 2016 р. чотири. Вони репрезентують радянський ностальгійний (2), регіональний (1) та національний (1) наративи.

Зокрема, у місті створили мурал із зображенням Н. Фатєєвої (рис. 14). Глава адміністрації Московського району Харкова О. Товкун підкреслив, що актриса $\epsilon$ харків'янкою, яка «знімалася в легендарних фільмах, iї пам’ятають і люблять». Її портрет мав стати «подарунком для всіх до Дня міста» ${ }^{27}$. Зображення відомої у СРСР актриси $\epsilon$ відлунням фантомного болю Харкова, яке він відчуває, знову опинившись на порубіж- 


$$
\begin{array}{r}
\text { Рuс. } 15 . \\
\text { Мурал } \\
\text { «Людмила }
\end{array}
$$

Гурченко»

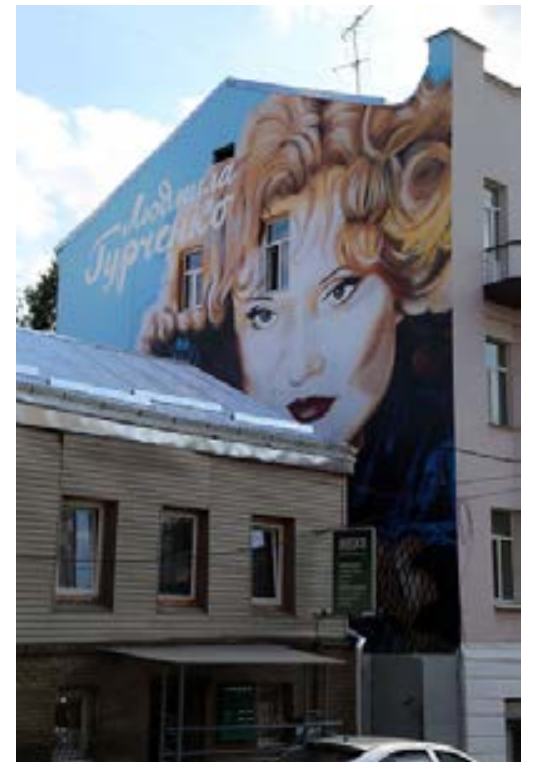

28 На доме в Харькове нарисовали портрет Людмилы Гурченко. Retrieved from https://www.city.kharkov.ua/ru/news/ na-budinku-v-kharkovi-namalyuvaliportret-lyudmili-gurchenko-32899.html.

29 Гигантский герб Харькова появился на Новгородской. Retrieved from https://redpost.com.ua/photo/ culture/1181274.html.

зө у Харкові створили мурал на честь героїв Крут. Retrieved from https:// espreso.tv/news/2016/01/29/u_kharkovi stvoryly_mural_na_chet_geroyìv_krut. жі. Міські еліти в такий спосіб намагаються нагадати усім, що Харків був у соге радянського проєкту, який досі «пам'ятають і люблять». Цю візію минулого уособлює також відома актриса Л. Гурченко (рис. 15). Зазначимо, що у новинах було акцентовано на тому, що мурал із іiі зображенням створено на будинку, у якому актриса пережила окупацію ${ }^{28}$. Це спроба влади вписати загалом деполітизовану постать Л. Гурченко у річище радянського наративу. Зображення, що символізують регіональний наратив, з'явились у місті за ініціативи небайдужих харків'ян (рис. 16) ${ }^{29}$.

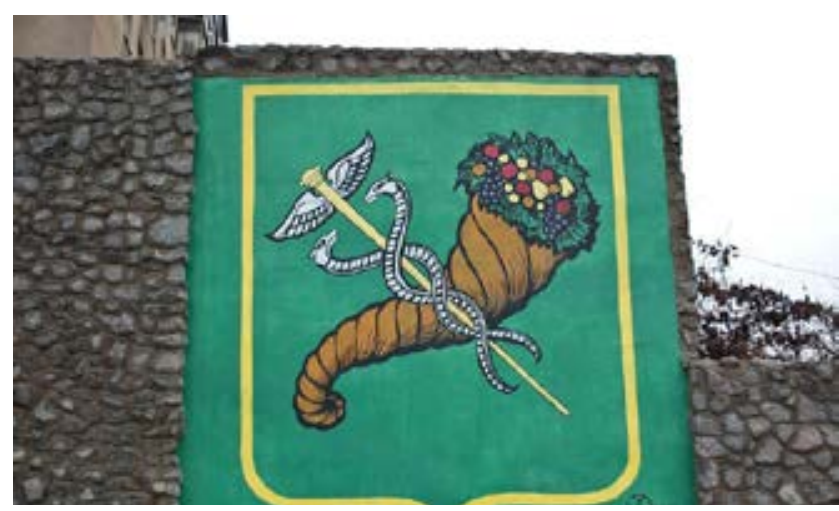

Рис. 16. Мурал «Герб Харкова»

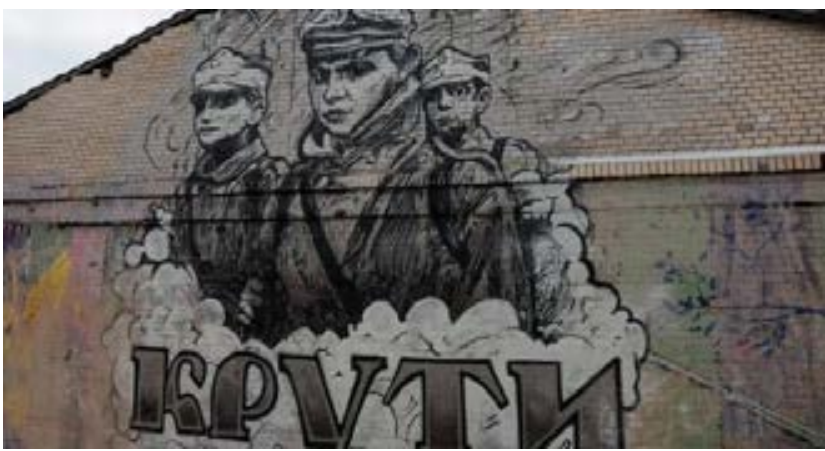

Рис. 17. Мурал «Герої Крут»

Вартий окремої уваги мурал на честь героїв Крут (рис. 17), що з'явився у місті у 2016 р. до 98-ї річниці бою під Крутами. За свідченням журналістів, «ініціаторами створення муралу виступили бійці "Азову" і “Східного корпусу”, які служили в зоні АТО» ${ }^{30}$. Вочевидь, зображення воїнів, що загинули у битві із радянськими військами, є інструменталізацією історичних подій. Річниця події не ювілейна, сама подія ніяк не пов'язана 3 Харковом. Тому можна констатувати, що це є спробою вписати Харків до національного наративу, продемонструвати перебування міста у core українського політичного проєкту.

Наступного року така тенденція продовжилася: у міському просторі з'явилися два семантично навантажені мурали, що репрезентують регіональний і національний на- 


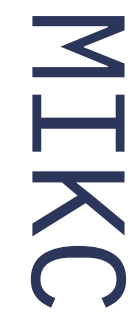



31 В Харькове появится мурал с изображением Успенского собора Retrieved from https://www.mediaport. ua/v-harkove-poyavitsya-mural-sizobrazheniem-uspenskogo-sobora.

32 Гігантський мурал в стилі петриківського розпису з'явиться в Харкові. Retrieved from https://www.slk.kh.ua/ news/kultura/gigantskij-mural-v-stilipetrikivskogo-rozpisu-zyavitsya-vkharkovi.html.

33 Возле цирка: в Харькове появился мурал с портретом дрессировщицы. Retrieved from https://kh.vgorode. ua/news/sobytyia/371496-vozle-

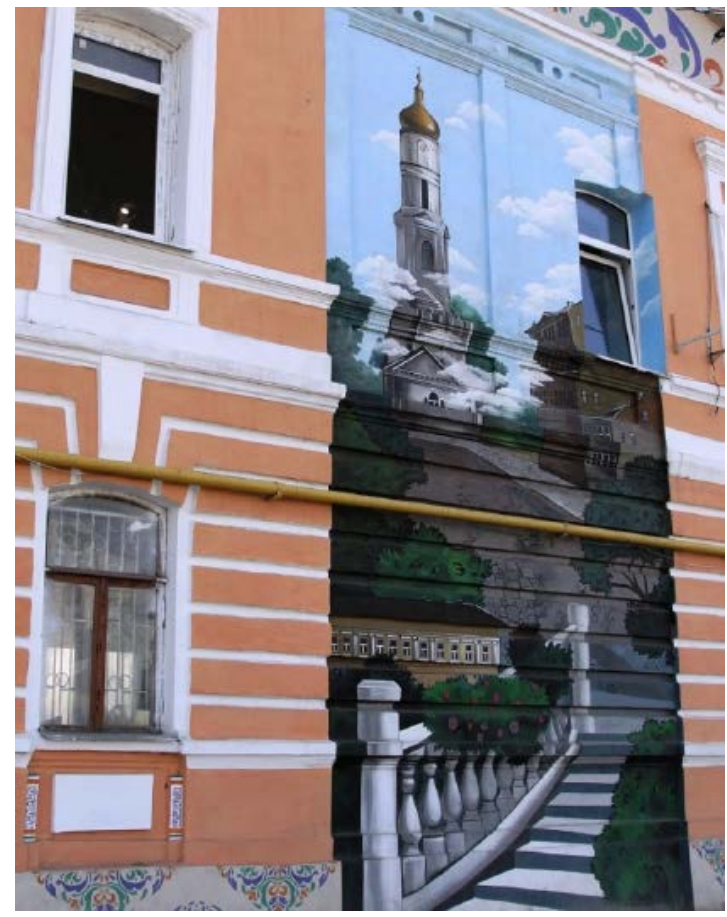

Рис. 18. Мурал «Успенський собор»

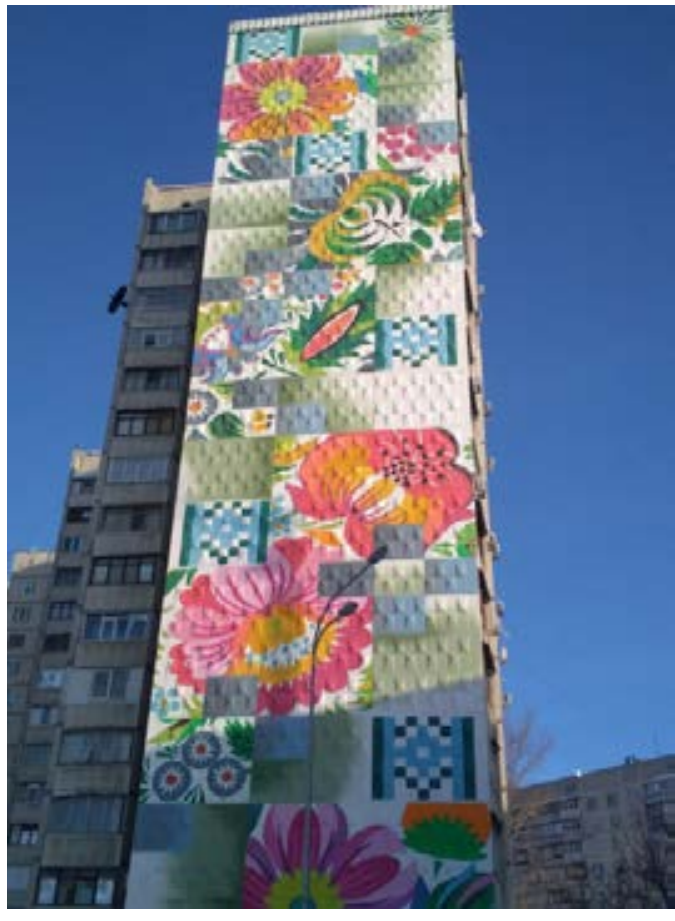

Рuc. 19. Мурал «Петриківський розпис» ративи. На першому зображено Успенський собор (рис. 18) - одну з найстаріших кам'яних будівель міста ${ }^{31}$, на другому - петриківський розпис (рис. 19), символ народного мистецтва ${ }^{32}$. Зауважимо, що петриківка як вид декоративного малярства характерний для центрального Подніпров'я, є типовим маркером українськості. Натомість апологети національного дискурсу в Харкові не апелюють до специфічного орнаменту вишивки, властивого саме Слобожанщині, - білим по білому. Хоча актуалізація цього могла б iз легкістю поєднати національний та регіональний наративи.

У 2018 р. знову бачимо відтворення радянського та національного образів Харкова. Зокрема, на одному з будинків, розташованих біля міського цирку, з'явилося зображення I. Бугримової (рис. 20) ${ }^{33}$. Критерії вибору персоналії $\epsilon$ типовими для Харкова - уродженка й мешканка Харкова, відома на загальносоюзному рівні. Винятком із 


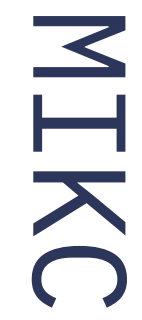

$$
\begin{array}{r}
\text { Рис. } 20 . \\
\text { Мурал } \\
\text { «Ірина }
\end{array}
$$

Бугримова»

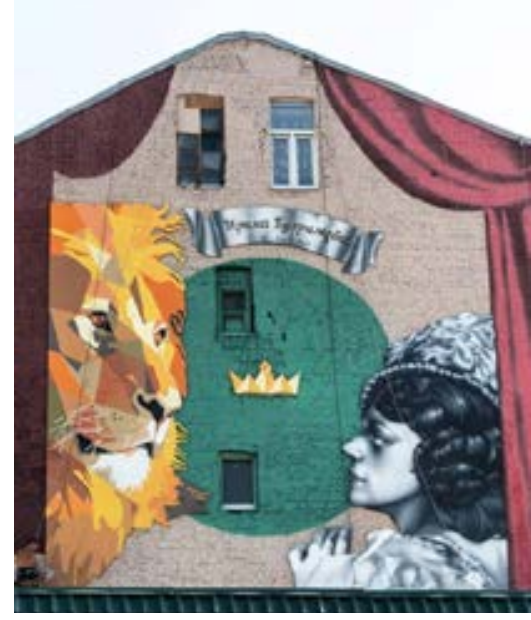

34 у Харкові 3'явився мурал з Кузьмою Скрябіним. Retrieved from

https://www.city.kharkov.ua/uk/news/ u-kharkovi-zyavivsya-mural-z-kuzmoyuskryabinim-38875.html.

35 Мурал И. 0. Дунаевскому в Харькове. Retrieved from https://gatta-bianka. livejournal.com/532888.html.

36 у Харкові заради піару Кернеса знищили мурал із Нобелівським лауреатом. Retrieved from https://kh.depo.ua/ukr/kh/ukharkovi-zaradi-piaru-kernesaznishchili-mural-iz-nobelivskimlaureatom-202007141188071.

цього правила є образ львів'янина К. Скрябіна (рис. 21), розташований у центрі міста біля філармонії. Біографія і творчість співака не пов'язані з Харковом. Його портрет було створено в межах Другого фестивалю графіті Kharkiv Mural Fest, що проводився під патронатом мера міста Г. Кернеса ${ }^{34}$. Патріотична позиція та волонтерська діяльність, популярність і трагічна смерть артиста вписали його до пантеону творців «нової України». Поява його образу у просторі міста є символічним проявом небайдужості Харкова до сучасного національного українського проєкту.

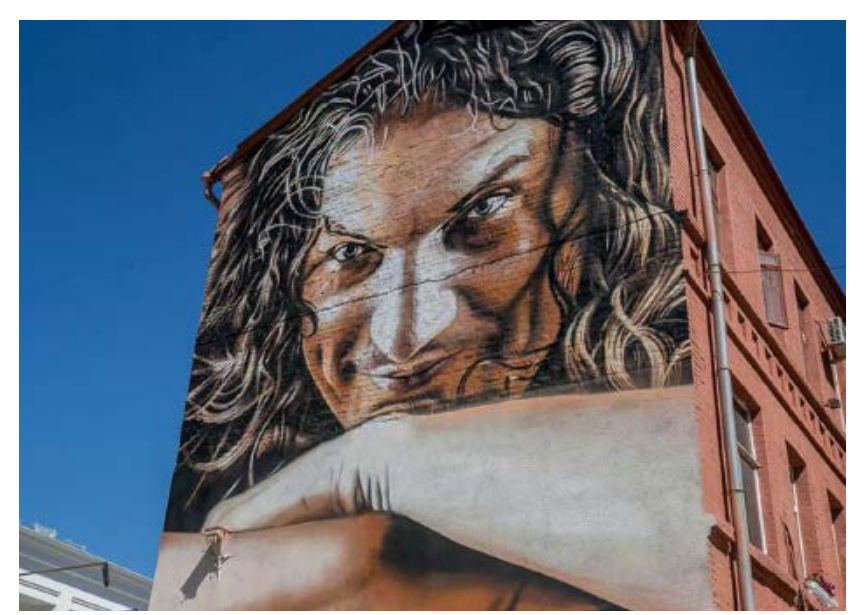

Puc. 21. Мурал «Кузьма Скрябін»

У 2019-2020 рр. можемо спостерігати ослаблення радянського дискурсу. Зокрема, iз п’яти муралів із символічним змістом до радянського наративу можна віднести лише зображення композитора I. Дунаєвського (рис. 22) ${ }^{35}$. Зауважимо, що інколи сюжети 3 регіональної історії, історії Харкова для чинної влади є більш значущими, ніж радянські. Приміром, під час передвиборчої кампанії на посаду мера міста, за ініціативи тодішнього керманича, було знищено мурал Л. Ландау, а на тому самому місці створено зображення символів Харкова (рис. 23) ${ }^{36}$. Образ

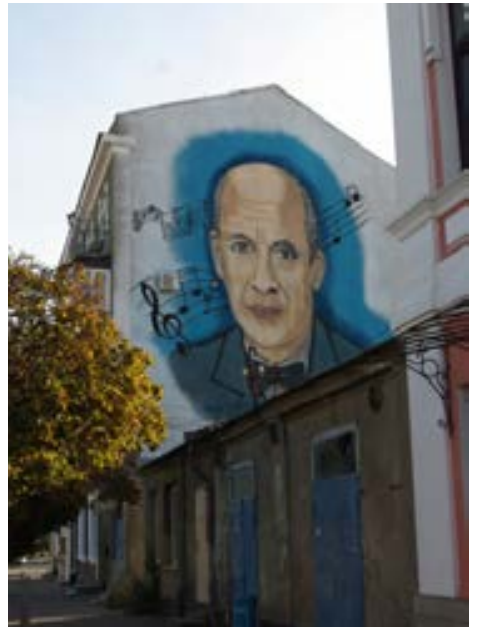

Рис. 22. Мурал «Ісаак Дунаєвський»

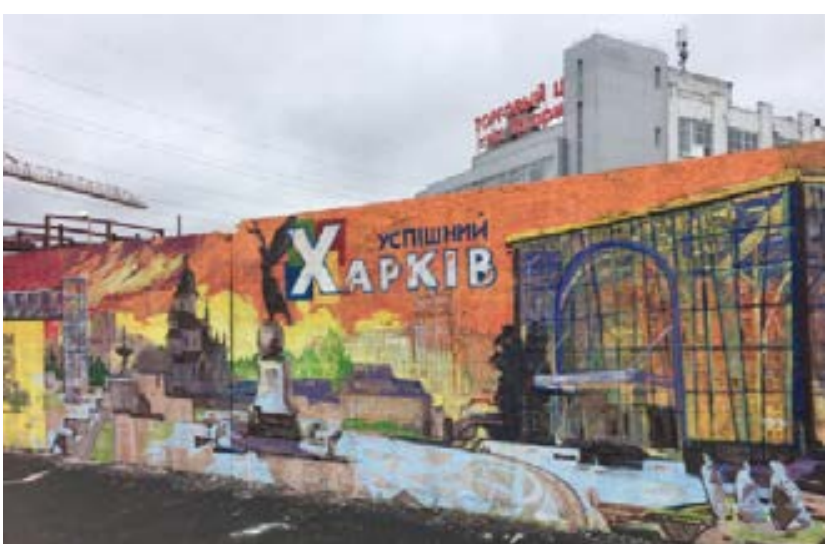

Рис. 23. Мурал «Успішний Харків» 


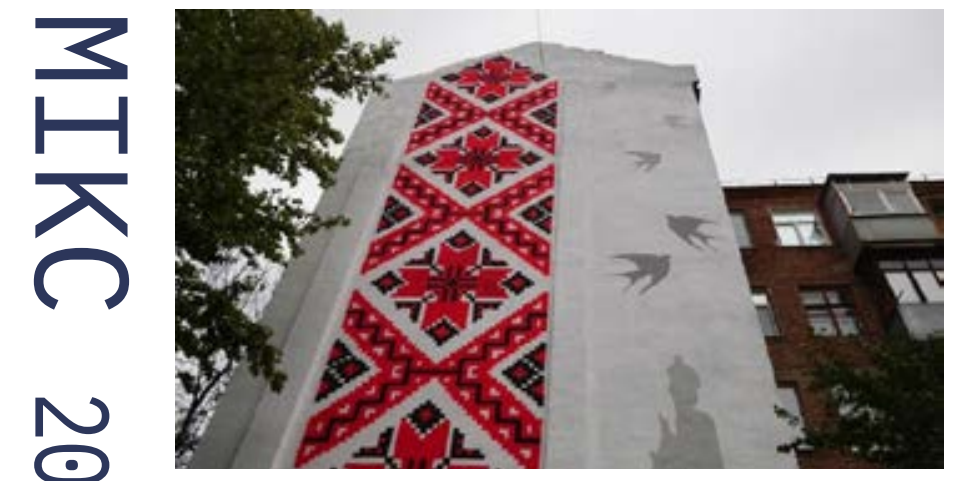

Рис. 24. Мурал «Вишиванка»

Puc. 25. Мурал «Контррозвідка поруч»
Л. Ландау відповідав усім канонам регіональної культури пам'яті: він працював у Харкові, був відомим у СРСР та у всьому світі. Втім, наголос на регіоналізмі та досягненнях сучасного міста для його очільників виявився важливішим. Інші мурали символізують залучення Харкова до національної культури (рис. 24) ${ }^{37}$, актуалізують проблему україно-російського протистояння на сході України (рис. 25) ${ }^{38}$.

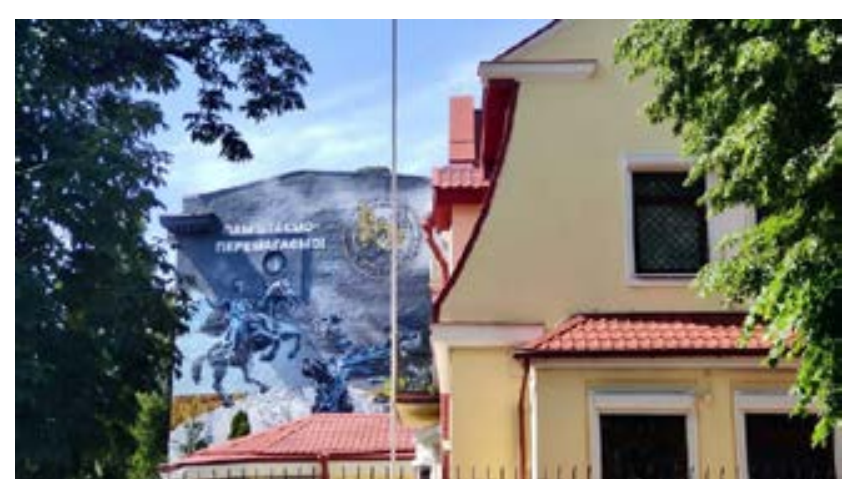

У 2019 р. було створено мурал у Лозовій, 37 Шевченко, вышиванка, птицы: в Харькове появился новый мурал. Retrieved from https://kh.vgorode.ua/news/ dosuh_y_eda/410200-za-99-000-vkharkove-poiavylsia-novyi-mural.

38 «Контррозвідка поруч»: у Харкові з'явився мурал для дипломатів Путіна. Retrieved from https://kh.depo.ua/ukr/ kh/kontrrozvidka-poruch-u-kharkovizyavivsya-mural-dlya-diplomativputina-202006111173434.

39 Під Харковом створили мурал в честь загиблих воїнів. Retrieved

from https://rubryka.com/2019/08/16/ mural-lozova/. під час ATO (рис. 26) ${ }^{39}$. Цей приклад свідчить про можливість на регіональному рівні як правило, не об'єднувався 3 іншими, навіть із регіональними. Тому нетиповим зображення у м. Лозова двох воїнів, які загинули: один - у лавах радянської армії в Афганістані, другий - у складі української армі поєднання дискурсів, які по суті є взаємозаперечними.

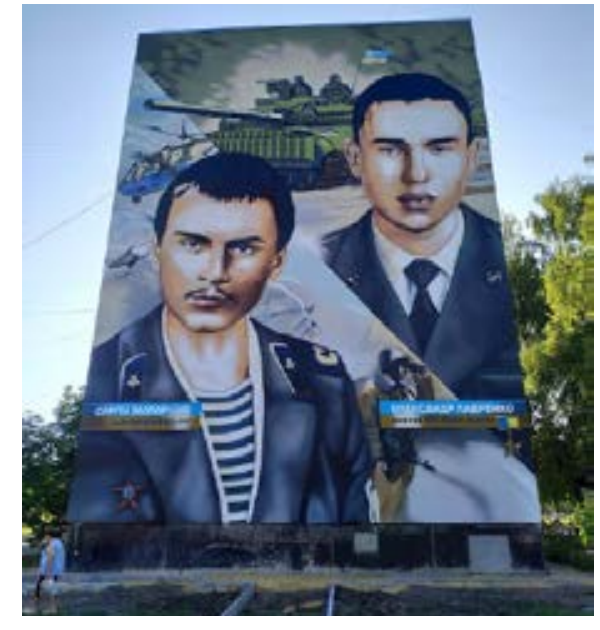

Puc. 26.

Мурал

«Сергій

Моторний i

Олександр

Лавренко»

Отже, аналіз муралів як медіаторів певного образу минулого у просторі Харкова засвідчив, що із 24 зображень, створених упродовж 2008-2020 рр., які мають яскраво виражене ідеологічне забарвлення, 13 демонструють належність Харкова до регіонального дискурсу, 12 - радянського, 10 національного. Можемо констатувати, що у 2008-2013 рр. у міському просторі переважно з'являлися мурали, що репрезентують радянсько-ностальгійний дискурс, який часто поєднується із регіональним. Зображення $\epsilon$ персоніфікованими. Одним із критеріїв відбору зображень була успішність діячів на загальносоюзному рівні. В такий спосіб міська влада, що зазвичай була ініціатором ïх створення, конструювала образ Харкова 
як успішного міста. Від 2014 р. у місті почали з'являтися мурали із зображенням загальнонаціональних символів, що можна інтерпретувати як спробу вписати Харків до національного наративу, продемонструвати перебування міста у соге українського політичного проєкту. Зазначимо, що національний наратив майже ніколи не поєднується 3 регіональним. Утім, зафіксовано випадки, коли радянсько-ностальгійний, регіональний і національний дискурси поєднувалися в одному зображенні.

\section{References}

Aleksandrov, Ye. (2003). Opyt rassmotreniya teoreticheskikh i metodologicheskikh problem vizual'noy antropologii. Moskva [in Russian].

Avanesov, S. Chto mozhno nazvat' vizual'noy semiotikoy? Praksema. Problemy vikhual'noy semiotiki, 1 10-22 [in Russian].

Bahatopoverkhivku v Kharkovi prykrasyv barvystyy mural. Retrieved from https://www.segodnya.ua/ua/ regions/kharkov/mnogoetazhku-v-harkove-ukrasil-krasochnyy-mural-744255.html [in Ukrainian].

Bozhenko, A. (2020). Stolychnyy Kharkiv: utopiya, konstruktyvizm, pamyat' (1919-1934 rr.). City History, Culture, Society, 8, 36-44 [in Ukrainian].

Chernomaz, P. (2012). Yevroregion "Slobozhanshchina": stanovleniye i rol' $\mathrm{v}$ razvitii ukrainsko-rossiyskogo transgranichnogo sotrudnichestva. Mezhdistsiplinarnyye issledovaniya $v$ nauke $i$ obrazovanii: Ekonomicheskiye nauki, 1. Retrieved from http://ekhnuir. univer.kharkov.ua/handle/123456789/6669 [in Russian]
Fotofart: teper' za KHTZ sledit Lev Landau. Retrieved from https://kh.vgorode.ua/news/dosuh y eda/184658-fotofakt-teper-za-khtz-sledyt-lev-landau [in Russian].

Hihantskyy mural v styli petrykivs'koho rozpysu z'yavyt'sya v Kharkovi. Retrieved from https://www.slk. kh.ua/news/kultura/gigantskij-mural-v-stili-petrikivskogo-rozpisu-zyavitsya-v-kharkovi.html [in Ukrainian].

Hyhantskyy herb Khar'kova poyavylsya na Novhorodskoy. Retrieved from https://redpost.com.ua/ photo/culture/1181274.html [in Russian].

Kas'yanov, H. (Ed.). (2018). Polityka i pam'yat'. Dnipro - Zaporizhzhya - Odesa - Kharkiv. Vid 1990-kh do s'ohodni. Lviv [in Ukrainian].

"Kontrrozvidka poruch": U Kharkovi z'yavyvsya mural dlya dyplomativ Putina. Retrieved from https:// kh.depo.ua/ukr/kh/kontrrozvidka-poruch-u-kharkovizyavivs y a - mural-dlya-diplomativ-put ina202006111173434 [in Ukrainian].

Kravchenko, V. (2010). Khar'kov/Kharkiv: stolytsa Pohranych'ya. Vyl'nyus: Evropeyskyy humanytarnyy unyversytet [in Russian].

Kul'turnyy proyekt "P'yatyy Kharkiv" rozpochynaye novyy sezon. Retrieved from https://kharkivoda. gov.ua/news/104979 [in Ukrainian].

Kovalevs'ka, O. (2018).Vizual'ni studiyi. In V. Smoliy (Ed.), Narysy z sotsiokul'turnoyi istoriyi ukrayins 'koho istoriyepysannya: subdystsyplinarni napryamy (pp. 119-184). Kyiv.

Mural Leonidu Bykovu. Retrieved from https://mural.kh.ua/bykov/ [in Russian]

Mural Taras Shevchenko. Retrieved from https:// mural.kh.ua/shevchenko/ [in Russian].

Mural Y. O. Dunaevskomu v Khar'kove. Retrieved from https://gatta-bianka.livejournal.com/532888.html [in Russian].

Mural Yuriy Gagarin. Retrieved from https://mural kh.ua/gagarin/ [in Russian] 
Musiyezdov, O. (2011). Identyfikatsiya Kharkova: dosvid konstruyuvannya obrazu mista. Skhid-Zakh id: Istoryko-kul'turolohichnyy zbirnyk, 15, 217-234 [in Ukrainian].

Na dome v Khar'kove narysovaly portret Lyudmyly Hurchenko. Retrieved from https://www.city.kharkov.ua ru/news/na-budinku-v-kharkovi-namalyuvali-portret-lyudmili-gurchenko-32899.html [in Russian].

Odnu iz sten khar'kovskogo doma ukrasil marshal Zhukov na val'siruyushchem kone. Retrieved from https://www.057.ua/news/706954/odnu-iz-sten-harkovskogo-doma-ukrasil-marsal-zukov-na-valsiruusemkone-fotofakt [in Russian].

Pid Kharkovom stvoryly mural v chest' zahyblykh voyiniv. Retrieved from https://rubryka.com/2019/08/16/ mural-lozova/ [in Ukrainian].

Portret Grizodubovoy velichinoy s dom - na Moskovskom prospekte. Retrieved from https:// www.mediaport.ua/portret-grizodubovoy-velichinoy-s-dom-na-moskovskom-prospekte [in Russian]

Posokhov, S. (2017). Profesiyni istoryky i polityka pam'yati $\mathrm{v}$ kharkivs'komu rehioni (doba nezalezhnoyi Ukrayiny). In Istoriohrafichni ta dzhereloznavchi prob lemy istoriyi Ukrayiny (pp. 277-291). Dnipropetrovsk [in Ukrainian].

Samyye krasivyye i kreativnyye muraly, art-ob'yekty i graffiti Khar'kova. Retrieved from https://mural. kh.ua/ [in Russian]

Shevchenko, vyshyvanka, ptytsy: v Khar'kove poyavylsya novyy mural. Retrieved from https://kh.vgorode. ua/news/dosuh y eda/410200-za-99-000-v-kharkovepoiavylsia-novyi-mural [in Russian].

Shtompka, P. (2007). Vizual'naya sotsiologiya. Fotografiya kak metod issledovaniya. Moskva [in Russian].

Top-12 muralov Khar'kova. Retrieved from https:// mykharkov.info/news/top-12-muralov-harkova-10027. html [in Russian].

U Kharkovi stvoryly mural na chest' heroyiv Krut Retrieved from https://espreso.tv/news/2016/01/29/u kharkovi_stvoryly_mural_na_chet_geroyiv_krut [in Ukrainian].

U Kharkovi zarady piaru Kernesa znyshchyly mural iz Nobelivs'kym laureatom. Retrieved from https://kh.depo.ua/ukr/kh/u-kharkovi-zaradi-piaru-kernesa-znishchili-mural-iz-nobelivskim-laureatom-202007141188071 [in Ukrainian].

U Kharkovi z'yavyvsya mural z Kuz'moyu Skryabinym. Retrieved from https://www.city.kharkov.ua/ uk/news/u-kharkovi-zyavivsya-mural-z-kuzmoyu-skryabinim-38875.html [in Ukrainian].

Ukrainskaya kukla-motanka. Retrieved from https:// mural.kh.ua/kukla-motanka/ [in Russian].

V Khar'kove poyavylos' 15-metrovoe patryotychnoe hraffyty. Retrieved from https://www.newsroom kh.ua/news/v-harkove-poyavilos-15-metrovoe-patriotichnoe-graffiti [in Russian].

V Khar'kove poyavyt·sya mural s yzobrazhenyem Uspenskoho sobora. Retrieved from https:/www.mediaport.ua/v-harkove-poyavitsya-mural-s-izobrazheniem-uspenskogo-sobora [in Russian].

V Khar'kove turistov "udivil" mural s "georgiyevskoy lentochkoy". Retrieved from https://kh.depo. ua/rus/kh/u-harkovi-turistiv-zdivuvav-mural-iz-georgiyivskoyu-strichkoyu-foto-20171129684617 [in Russian].

V voskresen'ye v Khar'kove proydet festival' "Den' odnoy ulitsy". Retrieved from https://www.city.kharkov. ua/ru/news/u-nedilyu-v-kharkovi-proyde-festival-denodniei-vulitsi-30615.html [in Russian].

Vozle tsyrka: v Khar'kove poyavylsya mural s portretom dressyrovshchytsy. Retrieved from https:// kh.vgorode.ua/news/sobytyia/371496-vozle-tsyrka-v-kharkove-poiavylsia-mural-dressyrovschytse-yryne-buhrymovoi [in Russian]

Zamyatin, D. (2010). Gumanitranaya geografiya: predmet izucheniya i osnovnyye napravleniya razvitiya. Obshchestvennyye nauki i sovremennost', 4, 126-138 [in Russian]. 


\section{Roman Liubavskiy}

\section{MURALS OF KHARKIV: SPASE, MEMORY, HISTORICAL POLITIKCS}

The article analyzes the murals of Kharkiv that appeared in the city during 2008-2020. They are considered as mediators of historical memory, retransmitting various narratives/discourses: Soviet-nostalgic, regional, national. 24 art objects located in the urban space have been analyzed, the context of their creation, the practice of their instrumentalization by various agents of historical memory have been revealed.

The city authorities are the initiators of the appearance of murals representing the Soviet-nostalgic discourse. Most of these images appeared in the city in 2013, on the eve of the celebration of the City Day and the celebration of the 70th anniversary of liberation from German occupation. The city leaders initiated the Pride of Kharkiv project, in the framework of which in the city appeared murals depicting Kharkiv residents, whose life and work are directly connected with the events of the Great Patriotic War. Among them are V. Grizodubova, G. Zhukov, K. Shulzhenko, P. Naboychenko. These and other images illustrate the Soviet-nostalgic and regional dimensions of the city's public space. They are often combined with each other, latently or directly actualizing the phantom pains of the "first capital". Such images are always personalized. Criteria for choosing a person include being a native and resident of Kharkiv, known at the All-Union level (L. Gurchenko, I. Bugrymova, etc.).

Since 2014, in the city we have observed the appearance of images of nationwide symbols, which can be interpreted as an attempt to fit Kharkiv into the national narrative, to demonstrate the city's presence in the core of the Ukrainian political project. Such murals are personalized and abstractsymbolic (T. Shevchenko, Krut's warriors-heroes, the coat of arms of Ukraine, Petrykivka painting, vyshyvanka (embroidered shirt) (ornament), motanka doll, etc.). The initiators of the creation of these murals are the city authorities and the city community. It should be noted that the national narrative was almost never combined with the regional one. However, there are cases when Soviet-nostalgic, regional and national discourses were projected in one image. Thus, there is a mural depicting both soldiers who died during the war in Afghanistan and during the anti-terrorist operation. This may indicate the multi-layered historical memory of the region's inhabitants.

To sum up, the analysis of murals as mediators of a certain image of the past in space of Kharkiv showed that out of 24 murals created during 2008-2020, which have a pronounced ideological coloring, 13 retransmit the Soviet-nostalgic narrative in Kharkiv, 12 - regional, 10 - national.

Keywords: murals, Kharkiv, public space, historical politics. 